\title{
A Family Study of the Late Infantile and Juvenile Forms of Metachromatic Leucodystrophy
}

\author{
H. S. SCHUTTA*, R. T. C. PRATT, H. METZ†, K. A. EVANS, and C. O. CARTER \\ From the Institute of Neurology, Queen Square, W.C.I, Department of Neurology, The Hospital for Sick Children, \\ and M.R.C. Clinical Genetics Research Unit, Institute of Child Health, 30 Guilford Street, London W.C.I
}

Classification within the disorder formerly known as diffuse sclerosis has been much improved in the past decade. Lumsden pointed out in $195 \mathrm{I}$ that Schilder (1912, 1913, 1924) had described three distinct conditions, the one in his I913 paper corresponding to what is now known as familial metachromatic leucodystrophy. In 1957 Hirsch and Peiffer introduced a new stain for metachromasia (cresyl violet in $1 \%$ acetic acid giving a golden brown colour), re-examined (Peiffer, 1962) the necropsy material from several earlier cases, and reclassified them in the group of metachromatic leucodystrophy.

The age of onset of metachromatic leucodystrophy exterds from infancy to adult life. The most homogeneous group of these is the late infantile, in which the age of onset is between 7 and 36 months, with a mode at II-24 months. The child develops a progressive weakness, incoordination of limb and eye movements, dysphagia, and then increasing spasticity and dementia. The latest age at death recorded in this group is 7 years, apart from one survivor at 8 years. Without exception, the affected sibs of patients with this form of the disease have had a similar form of the disease. There has been little discussion of the genetics of the condition, with the exception of Jervis (1960) who suggested that the condition was autosomal recessive, and no family study of a consecutive series of index patients has yet been reported.

The group of leucodystrophies with a later onset is heterogeneous. In a few families there is clear evidence of a dominant mode of inheritance with a wide range of age of onset, and the duration of

\footnotetext{
Received September 20, 1965.

* Present address: Department of Neurology, Pennsylvania Hospital, Philadelphia, U.S.A.

† Present address: 26 rue Goethe, Luxembourg.
}

the illness may be more than 20 years (Poserş Dewulf, and van Bogaert, 1957). Other familiesw (Scholz, I925; Walthard, 1933; Pfister, 1936 Curtius, 1930; Hoefnagel, van den Noort, ando Ingbar, 1962) show a probable recessive X-linkedf inheritance with occasional manifestation in females: in this group there may be clinical evidence of skin pigmentation and, at necropsy, adrenal atrophy. Other adult cases are isolated.

When these three subgroups are excluded, the remainder appears to form a homogeneous group; with age of onset between 4 and Io years, theo duration of the illness from I to I I years, and the earliest recorded age at death 7 years; there is however, a male preponderance.

\section{Present Study}

No families suggesting dominant inheritance or $\mathrm{X}$ linked inheritance were seen in this series from ao children's hospital, and all the patients studied in this series may be classed as late infantile or juvenile.

Material. The index patients for this family study were all those in whom the diagnosis of metachromatico leucodystrophy had been established on clinical and histological evidence at The Hospital for Sick Childreno from 1950 through 1963 . There were 17 such patients, including two pairs of sibs. The histological and $\frac{D}{0}$ clinical findings on these index patients are summarized in Table I. The nerve conduction times recorded in N the right hand column of the table were done by Fuller-ton (1964), who has reported the findings in 7 of them.

Twelve ( 4 boys and 8 girls) may be readily classified as 'late infantile', all with an onset between 12 and 240 months. Of these, 9 are dead, all dying at ages between $2 \frac{1}{2}$ years and $5 \frac{1}{2}$ years. Another male index patient (No. 응 8) had an early onset ( 16 months), and was the elder( brother of a girl typical of the infantile form of the ${ }^{+}$ disease, but did not die until aged 7 years 8 months. $\mathrm{He}-\frac{0}{5}$ has been included among the late infantile cases. The $\frac{\vec{\Phi}}{\mathbb{D}}$ remaining 2 were still alive at the ages of 4 years $5 \%$ months and 5 years 8 months. 
TABLE I

\begin{tabular}{|c|c|c|c|c|c|c|c|c|c|c|c|c|}
\hline \multirow{2}{*}{$\begin{array}{l}\text { Serial } \\
\text { No. }\end{array}$} & \multirow{2}{*}{ Sex } & \multirow{2}{*}{$\begin{array}{c}\text { Date } \\
\text { Admitted }\end{array}$} & \multirow{2}{*}{$\begin{array}{c}\text { Date } \\
\text { of } \\
\text { Birth }\end{array}$} & \multirow{2}{*}{$\begin{array}{c}\text { Age } \\
\text { at } \\
\text { Onset } \\
\text { (mth.) }\end{array}$} & \multirow{2}{*}{\multicolumn{2}{|c|}{$\begin{array}{l}\text { Age at } \\
\text { Death* }\end{array}$}} & \multicolumn{4}{|c|}{ Metachromasia on Biopsy or at Necropsy $\dagger$} & \multirow[b]{2}{*}{ Skin } & \multirow{2}{*}{$\begin{array}{c}\text { Lowered } \\
\text { Nerve } \\
\text { Conduction }\end{array}$} \\
\hline & & & & & & & $\begin{array}{l}\text { Urine } \\
\text { or } \\
\text { Kidney }\end{array}$ & $\begin{array}{c}\text { Rectal Biopsy } \\
\text { or } \\
\text { Gastro-intestinal }\end{array}$ & Nerve & Brain & & \\
\hline $\begin{array}{r}1 \\
2 \\
3 \\
4 \\
5 \\
6 \\
7 \\
8 \\
9 \\
10 \\
11 \\
12 \\
13 \\
\end{array}$ & $\begin{array}{l}M \\
M \\
F \\
M \\
F \\
M \\
F \\
M \\
F \\
F \\
F \\
F \\
F\end{array}$ & $\begin{array}{r}5 / 50 \\
3 / 54 \\
4 / 54 \\
3 / 56 \\
6 / 56 \\
7 / 57 \\
10 / 59 \\
12 / 57 \\
11 / 62 \\
4 / 62 \\
5 / 63 \\
8 / 63 \\
9 / 63 \\
\end{array}$ & $\begin{array}{r}3 / 45 \\
1 / 52 \\
2 / 52 \\
1 / 53 \\
4 / 50 \\
11 / 55 \\
11 / 55 \\
6 / 56 \\
8 / 58 \\
3 / 60 \\
1 / 61 \\
1 / 60 \\
11 / 59 \\
\end{array}$ & $\begin{array}{l}18 \\
14 \\
16 \\
21 \\
24 \\
12 \\
24 \\
16 \\
12 \\
16 \\
20 \\
18 \\
18\end{array}$ & $\begin{array}{l}5 \\
2 \\
4 \\
4 \\
6 \\
3 \\
4 \\
7 \\
4 \\
4 \\
2 \\
4 \\
(5 \\
\end{array}$ & $\begin{array}{l}2 \\
7 \\
0 \\
4 \\
4 \\
3 \\
8 \\
8 \\
9 \\
9 \\
7 \\
5) \\
8)\end{array}$ & $\begin{array}{l}+ \\
+ \\
+ \\
+ \\
+ \\
+ \\
+ \\
+ \\
+ \\
+\end{array}$ & $\begin{array}{l}+ \\
+ \\
+ \\
+ \\
+ \\
+\end{array}$ & $\begin{array}{l}+ \\
+ \\
+ \\
+ \\
+\end{array}$ & $\begin{array}{l}+ \\
+ \\
+ \\
+ \\
+ \\
+ \\
+ \\
+\end{array}$ & $\begin{array}{l}+ \\
+ \\
+ \\
+ \\
+\end{array}$ & $\begin{array}{l}+ \\
+ \\
+ \\
+ \\
+\end{array}$ \\
\hline $\begin{array}{l}14 \\
15 \\
16 \\
17\end{array}$ & $\begin{array}{l}M \\
M \\
M \\
F\end{array}$ & $\begin{array}{l}4 / 54 \\
5 / 62 \\
3 / 63 \\
4 / 63\end{array}$ & $\begin{array}{r}10 / 50 \\
12 / 53 \\
5 / 58 \\
5 / 54\end{array}$ & 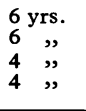 & $\begin{array}{l}\text { IO } \\
\text { (1 I } \\
\text { (6 } \\
\text { (10 }\end{array}$ & $\begin{array}{l}4 \\
\text { 1) } \\
\text { 1) } \\
6)\end{array}$ & $\begin{array}{l}+ \\
+ \\
+\end{array}$ & $\begin{array}{l}+ \\
+ \\
+\end{array}$ & + & $\begin{array}{l}+ \\
+ \\
+\end{array}$ & $\begin{array}{l}+ \\
+ \\
+\end{array}$ & $\begin{array}{l}- \\
+ \\
+\end{array}$ \\
\hline
\end{tabular}

* Those still alive are in parentheses.

+ If examined and found negative they are shown as -.

Of the other index patients, 4 ( 3 boys and I girl) may be readily classified as belonging to the juvenile form with onset between 4 years and 7 years; one of these patients died at the age of ro years and 4 months, and the other 3 were still alive at the ages of 6 years I month, Io years 6 months, and I I years I month.

The post-mortem histological features of 4 of these children and the biopsy findings on 4 others have been reported (Bodian and Lake, 1963). Their post-mortem Cases I, 2, 7, and 5, and their surgical Cases I, 2, 3, and 4 are our patients $I, 2,3,6,15,10,8$, and 9, respectively.

Methods. The families of the index patients were visited in their own homes and a family history was taken, paying special attention to the possibility of consanguinity. Hospital records and death certificates were obtained on sibs and other relatives who were possibly affected.

\section{Genetic Findings}

Sex Ratio. The sex ratio of the index patients, 5 male to 8 female for the late infantile, and 3 to $I$ for the juvenile, does not differ significantly from unity.

Parental Consanguinity. None of the parents seen. were known to be blood relatives, and there is no suggestion that grand-parents of affected individuals came unduly often from any particular part of Britain.

Twins. None of the index patients was twin born.

Sibs. The sibships of the index patients are tabulated in Appendix I and are summarized in Table II (excluding two dying in infancy) for the infantile and juvenile series, respectively. Of 25 sibs of the late infantile index patients, 7 had similar late infantile metachromatic leucodystrophy, and 3 of the 5 sibs of the juvenile type index patients had the juvenile form of the disease.
Information on the sibs classed as probably affected is summarized in Appendix II.

Half-sibs. 7 male and 3 female half-sibs of the late infantile patients were all unaffected.

\section{TABLE II}

SIBS OF INDEX PATIENTS WITH LATE INFANTILE AND JUVENILE FORMS OF METACHROMATIC LEUCODYSTROPHY (NUMBER AFFECTED SHOWN IN BRACKETS)

\begin{tabular}{c|c|c|c|c|c}
\hline & \multicolumn{2}{|c|}{$\begin{array}{c}\text { Sibs Before } \\
\text { Index Patient }\end{array}$} & \multicolumn{2}{|c|}{$\begin{array}{c}\text { Sibs After } \\
\text { Index Patient }\end{array}$} & Total \\
\cline { 1 - 3 } & Male & Female & Male & Female & \\
\cline { 1 - 4 } $\begin{array}{c}\text { Late infantile } \\
\text { (13 cases) }\end{array}$ & 10 & Io & 2 & 3 & 25 \\
Juvenile & $(4)$ & $(2)$ & $(0)$ & $(1)$ & $(7)$ \\
(5 cases) & 0 & I & 2 & 2 & 5 \\
$(0)$ & $(1)$ & $(2)$ & $(0)$ & $(3)$ \\
\hline
\end{tabular}

Other Relatives. No other relatives were found affected. For the late infantile group the numbers of other relatives (counting the family with two index patients twice) were: mother's brothers and sisters 13 and 39, father's brothers and sisters 25 and 24, mother's brother's sons and daughters 9 and Io, mother's sister's sons and daughters 25 and 37, father's brother's sons and daughters 25 and 22, father's sister's sons and daughters 20 and 18 . For the juvenile cases, again using a double count for the family with two index patients, the number of relatives were ro and 5, 4 and I, 6 and 7, I and I, 3 and 2, 0 and 3, respectively. In the two families with only male index patients, the mothers had 8 brothers who were all normal, and I mother had a sister's son who was normal.

\section{Discussion}

The 46 previously published reports, not all 
studied by modern histological methods, but generally accepted as the late infantile form of metachromatic leucodystrophy, are listed in Appendix IIIA. Assuming one index patient per sibship, these patients between them had 82 sibs, of whom 25 were proved or probably affected. In 2 instances the parents were consanguineous (first cousins: Marggraf, 1939; second cousins: Hariga, I960); consanguinity was absent in 20 and not recorded in 24. The proportion of sibs affected is higher than $I$ in 4 , but this is to be expected in the early years of recognition of a disease when the diagnosis is facilitated by a familial incidence and where the family history is incompletely reported. The sex ratio, 36 male to 34 female (not stated in I) is close to unity. There are only two reports of a relative other than a sib being affected, one was of a male second cousin (Hagberg, Sourander, Svennerholm, and Voss, 1960), the other was of two cousins of a patient reported by Austin (1957).

The recessive inheritance suggested by these case reports of the late infantile form is strongly supported by the proportion of sibs affected in the present series. If one assumes that the two index patients in the same family in our series were independently ascertained, this proportion is 7 in 25 , or, if one assumes that only I of these 2 children was truly an index patient, the proportion is 6 in 24. The sex ratio, 5 male to 8 female for the index patients, and 3 male to 2 female for affected sibs other than index patients, does not differ significantly from unity. The absence of parental consanguinity is perhaps surprising, but the cousin marriage rate in England is now probably very low indeed.

The 16 reported families of juvenile metachromatic leucodystrophy, excluding patients with clearly dominant or X-linked pedigrees, are listed in Appendix IIIB. There is a male preponderance, I8 male : 9 female ( 3 not recorded), though this does not differ significantly from unity. Assuming one index patient per sibship, these patients between them had 45 sibs of whom I4 were affected. There were no instances of parental consanguinity for the 8 families where information on this point was given. Recessive inheritance is suggested, but it is probable that some instances of X-linked recessive inheritance, not revealed by the pedigree, have been included, since not all such cases have pigmentation and the state of the adrenals at necropsy is not always reported.

Again the findings in the present small series of juvenile cases is compatible with recessive inheritance. There were affected 3 in 5 sibs, or 2 in 4 sibs, if only one of the family which includes Cases
16 and 17 is regarded as an index patient. The sex ratio of 3 male to I female index patient with one other male sib affected adds slightly to the male preponderance seen in the reported cases.

In this series affected sibs, as shown in Append产 II, without exception have run a course very similer to that of the index patient.

\section{Summary}

Between 1950 and 1963 at The Hospital for Siêk Children, London, 17 patients have been admitted with the clinical features of metachromatic leucos dystrophy, and in all these the diagnosis has begh confirmed by modern methods of staining. Of these, I3 may be classified as examples of the 'lape infantile' form of the disease with onset between the ages of 12 and 24 months, and death in the first decade. The other 4 may be classed as examples of the 'juvenile type' with onset between the agos of 4 and ro years.

The proportion of sibs affected in the families of this consecutive series of index patients suggests autosomal recessive inheritance for both the 'late infantile' and 'juvenile' forms of the disorder; byt there were no instances of parental consanguinity.

\section{RERERENCES}

Austin, J. H. (1957). Metachromatic form of diffuse cerebral sclea sis. I. Diagnosis during early life by urine sediment examination. Neurology (Minneap.), 7, 415.

Bodian, M., and Lake, B. D. (1963). The rectal approach to neuropathology. Brit. F. Surg., 50, 702.

Curtius, F. (1930). Familiäre diffuse Sklerose und familiäre sprg ische Spinalparalyse in einer Sippe. Z. ges. Neurol. Psychiat., 126, 209.

Fullerton, P. M. (1964). Peripheral nerve conduction in metachromatic leucodystrophy (sulphatide lipidosis). $f$. Neurgl. Neurosurg. Psychiat., 27, 100.

Hagberg, B., Sourander, P., Svennerholm, L., and Voss, H. (196). Late infantile metachromatic leucodystrophy of the genetic tyge. Acta paediat. (Uppsala), 49, 135.

Hariga, J. (I960). Deux observations de leucodystrophie, arec présence dans l'urine de graisses métachromatiques. F. Gérét. hum., $9,87$.

Hirsch, T. V., and Peiffer, J. (1957). A histochemical study of the pre-lipid and metachromatic degenerative products in leusodystrophy. In Cerebral Lipidoses, ed. L. van Bogaert, J. N. Cumings, and A. Lowenthal, pp. 68-76. Blackwell, Oxford.

Note

Hoefnagel, D., van den Noort, S., and Ingbar, S. H. (1962). Differe cerebral sclerosis with endocrine abnormalities in young males. Brain, 85, 553.

Jervis, G. A. (I960). Infantile metachromatic leukodystrophy (Gre field's disease). F. Neuropath. exp. Neurol., 19, 323.

Lumsden, C. E. (195I). Fundamental problems in the patholegy of multiple sclerosis and allied demyelinating diseases. Reit. med. F., $1,1035$.

Marggraf, K. (1939). Zur Frage der mit Lipoidspeicherung h $_{\text {- }}$ hergehenden Heredodegenerationen des Gehirns. Verh. Ges. Verdau u. Stoffwechselkrankh., 14, 108.

Peiffer, J. (1962) Differentiation of various types of leucodystropty. Wld Neurol., 3, 580.

Pfister, R. (1936). Beitrag zur Kenntnis der diffusen Hirnsklerege. Arch. Psychiat. Nervenkr., ro5, I. 
Poser, C. M., Dewulf, A., and van Bogaert, L. (1957). A typical cerebellar degeneration associated with leucodystrophy. $\mathcal{f}$. Neuropath. exp. Neurol., 16, 209.

Schilder, P. (Io12). Zur Kenntnis der sogennanten diffusen Sklerose. Z. ges. Neurol. Psychiat., 10, I.

- (1913). Zur Frage der Enzephalitis periaxialis diffusa (sogennante diffuse Sklerose). ibid., 15, 359.
- (1924). Die Enzephalitis periaxialis diffusa. Arch. Psychiat. Nervenkr., 71, 327.

Scholz, W. (1925). Klinische pathologisch-anatomische und erbbiologische Untersuchungen bei familiärer, diffuser Hirnsklerose im Kindersalter. Z. ges. Neurol. Psychiat., 99, 65I.

Walthard, K M. (1933). Familiäre diffuse Hirnsklerose. Schweiz. Arch. Neurol. Psychiat., 32, 25 I.

\section{APPENDIX I}

Index patients are marked with an asterisk; affected sibs are in italics

$M=$ male, $\mathbf{F}=$ female, $\mathrm{m}=$ miscarriage, $[\mathrm{]}=$ twins

\begin{tabular}{|c|c|c|c|c|c|c|}
\hline \multirow{2}{*}{$\begin{array}{l}\text { Serial } \\
\text { No. }\end{array}$} & \multirow{2}{*}{\multicolumn{2}{|c|}{ Patient, date of birth, and sibship }} & \multicolumn{2}{|c|}{ Half-sibs } & \multicolumn{2}{|c|}{ Date of Birth } \\
\hline & & & Maternal & Paternal & Mother & Father \\
\hline \multicolumn{7}{|c|}{ Late Infantile Metachromatic Leucodystrophy } \\
\hline $\begin{array}{r}10 \\
3\end{array}$ & $\begin{array}{l}F^{*} 3.60(\text { d. } 12.64) \\
F^{*} 2.52(\text { d. } 2.56)\end{array}$ & One-child families & MMF & MMMFF & $\begin{array}{l}I / 4 I \\
9 / 15\end{array}$ & $\begin{array}{r}1 / 36 \\
107\end{array}$ \\
\hline $\begin{array}{r}8,9 \\
2 \\
13\end{array}$ & $\begin{array}{l}\mathrm{m} 6.55 ; M^{*} 6.56(\mathrm{~d} .2 .64) ; F^{*} 8.58(\mathrm{~d} .5 .63) \\
M 6.47(\mathrm{~d} .3 .50) ; \mathrm{m}-.50 ; M^{*} \mathrm{I} .52(\mathrm{~d} .8 .54) \\
F^{*} \text { II.59; }{ }_{7.62}\end{array}$ & Two-child families & & & $\begin{array}{r}12 / 31 \\
6 / 23 \\
9 / 34\end{array}$ & $\begin{array}{r}1 / 30 \\
10 / 20 \\
10 / 33\end{array}$ \\
\hline $\begin{array}{l}\text { I } \\
5\end{array}$ & $\begin{array}{l}M_{1.33 ; M}-.37(\text { d. }-.40) ; M^{*} 3.45(\text { d. } 5.50) \\
F_{7.45 ; F^{*} 4.50(\text { d. } 8.56) ; F_{12} .5 I}\end{array}$ & Three-child families & & & $\begin{array}{l}3 / 13 \\
9 / 21\end{array}$ & $7 / 08$ \\
\hline $\begin{array}{l}12 \\
7\end{array}$ & 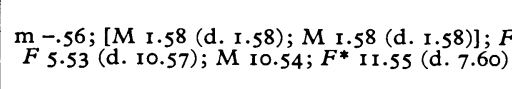 & $\begin{array}{l}\text { Four-child families } \\
\text { I.60; M 6.61 } \\
\text { F } 12.59\end{array}$ & & & $\begin{array}{l}1 / 31 \\
2 / 23\end{array}$ & $\begin{array}{r}12 / 28 \\
9 / 22\end{array}$ \\
\hline $\begin{array}{l}4 \\
6\end{array}$ & 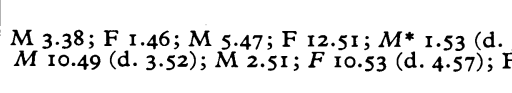 & $\begin{array}{l}\text { Five-child families } \\
57) \\
\text { I0.54; } M^{*} \text { II. } 55 \text { (d. 2.59) }\end{array}$ & M & MF & $\begin{array}{r}9 / 13 \\
12 / 12\end{array}$ & $\begin{array}{l}5 / 13 \\
5 / 06\end{array}$ \\
\hline I I & F 9.38; $M$ 10.40 (d. 3.44); F 8.42; F I.44; F 9 & $\begin{array}{l}\text { Six-child families } \\
7 ; F^{*} \text { I.6I (d. 8.63) }\end{array}$ & & & $3 / 20$ & $10 / 09$ \\
\hline \multicolumn{7}{|c|}{ Juvenile Metachromatic Leucodystrophy } \\
\hline $\begin{array}{l}16,17 \\
14\end{array}$ & $\begin{array}{l}\mathrm{m}-.53 ; F^{*} 5.54 ; M^{*} 5.58 \\
M^{*}{ }_{10.50}\left(\mathrm{~d}^{2} 2.6 \mathrm{I}\right) ; \mathrm{F}^{\mathrm{I}} 2.53 \\
\mathrm{~m}-.52 ; M^{*} \mathrm{I} 2.53 ; M_{4} 4.57 ; \mathrm{F} 7.59\end{array}$ & Three-child families & & & $\begin{array}{l}8 / 23 \\
8 / 20 \\
5 / 29\end{array}$ & $\begin{array}{r}120 \\
5 / 20 \\
12 / 28\end{array}$ \\
\hline
\end{tabular}

\section{APPENDIX II}

\section{Affected Sibs of Index Cases (excluding those who are themselves index cases)}

\begin{tabular}{l|l}
\hline Family 2 & $\begin{array}{c}\mid c \\
\text { Late Infantile Form }\end{array}$ \\
Elder brother, born 6.47, died 2 years 9 months; \\
onset age 24 months; signs of progressive cerebral \\
degeneration; diagnosis at Chester City Hospital- \\
Schilder's disease
\end{tabular}

Family 6 Elder brother, born 10.49, died 2 years 5 months; onset age 23 months; diagnosis at The Hospital for Sick Children-Schilder's disease

Elder sister, born ro.53, died 3 years 6 months; signs of progressive cerebral degeneration; brain biopsy at The National Hospital showed metachromatic leucodystrophy

Family I I Elder brother, born ro.40, died 3 years 6 months; onset age 20 months; mother's description of illness very much like that of index patient; death certified as due to 'spastic diplegia'

Juvenile Form

Juvenile Form Younger brother, born 4.57, still alive aged 8 years 2 months; onset age 6 years 9 months: diagnosis confirmed by metachromatic granules in urine at age 7 years 5 months 


\section{APPENDIX III}

\section{Published Reports of Late Infantile Metachro- matic Leucodystrophy and of Juvenile Meta- chromatic Leucodystrophy}

$\mathbf{M}=$ male, $\mathbf{F}=$ female, $\mathbf{N}=$ sex not stated, italics $=$ affected, $-=$ no consanguinity, n.r. = not reported, $t=$ consanguinity, []$=$ twins ? = not possible to check original paper.

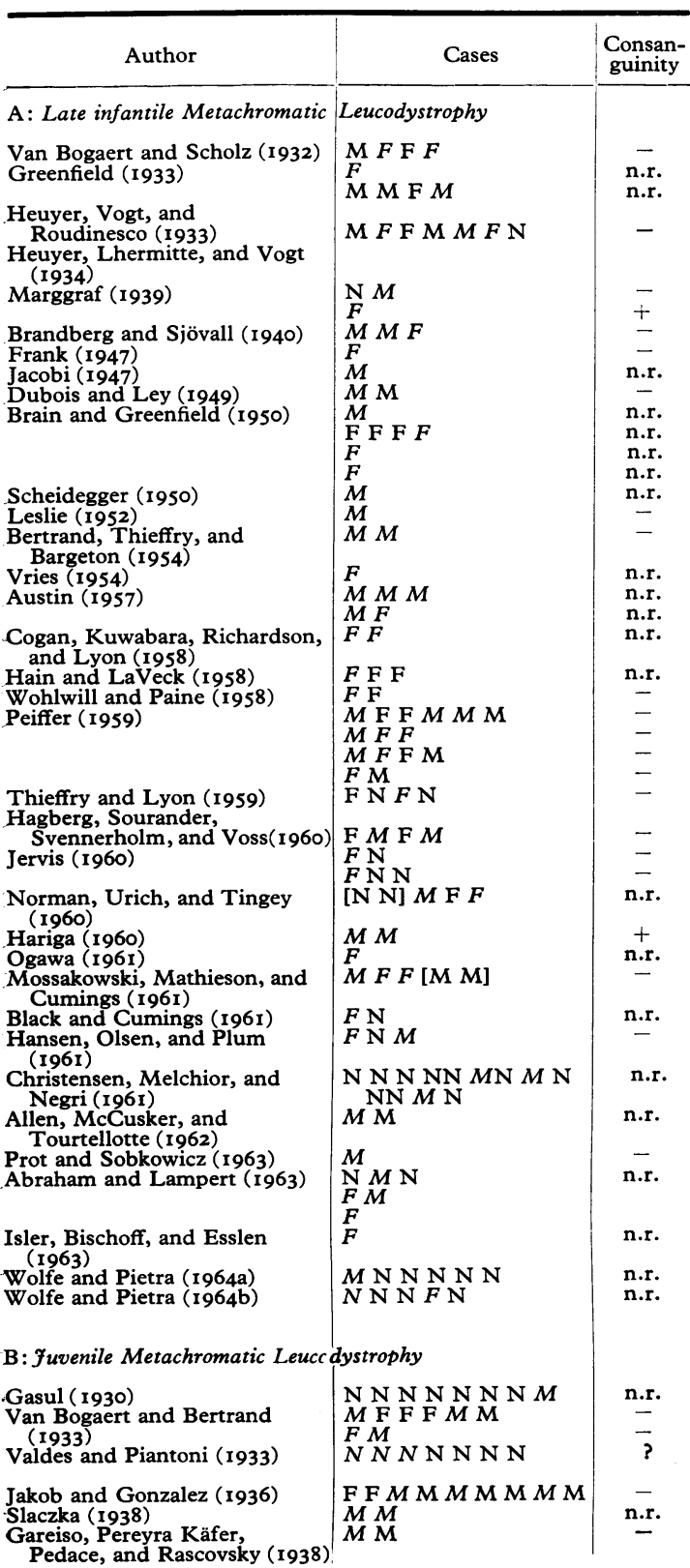

\begin{tabular}{|c|c|}
\hline $\begin{array}{l}\text { Lange (1946) } \\
\text { Lange (1947) } \\
\text { Brusa (1952) } \\
\text { Kufs, Lange-Cosac', and } \\
\text { Suckow (1954) } \\
\text { Cumings (1955) } \\
\text { Diezel (1957) } \\
\text { Cogan et al. (1958) } \\
\text { Scheidegger (1959) } \\
\text { Lyon, Arthuis, and Thieffry } \\
\text { (1961) } \\
\text { Kalicanin (r96?) }\end{array}$ & $\begin{array}{l}M M F \\
\mathrm{~F} F M M \\
F F F \mathrm{~F} \\
F \\
M M \\
M \\
\mathrm{~N} F M \mathrm{~N} \\
M F\end{array}$ \\
\hline
\end{tabular}

\section{REFERENCES IN APPENDIX III}

Abraham, K., and Lampert, P. (1963). Neurology (Minneap.), Allen, R. J., McCusker, J. J., and Tourtellotte, W. W. (1962). Pediatrics, 30, 629.

Austin, J. H. (1957). Neurology (Minneap.), 7, 415.

Bertrand, I., Thieffry, S., and Bargeton, E. (I954). Rev. neur 91,161 .

Black, J. W., and Cumings, J. N. (196I). F. Neurol. Neurosu*g. Psychiat., 24, 233.

Brain, W. R., and Greenfield, J. G. (1950). Brain, 73, 29 r.

Brandberg, O., and Sjövall, E. (1940). Z. ges. Neurol. Psychiăt I70, 13 I.

Brusa, A. (1952). Minerva pediat., 4, 813.

Christensen, E., Melchoir, J. C., and Negri, S. (196r). Acta neur scand., 37, 163 .

Cogan, D. G., Kuwabara, T., Richardson, E. P., and Lyon, (1958). Arch. Ophthal., 60, 397.

Cumings, J. N. (1955). Brain, 78, 554.

Diezel, P. B. (1957). Die Stoffwechselstörungen der Sphingolipoides p. 192. Springer, Berlin.

Dubois, R., and Ley, R.-A. (1949). Acta neurol. belg., 49, 13.

Frank, J. (1947). Arch. Psychiat. Nervenkr., 179, 146.

Gareiso, A., Pereyra Käfer, J., Pedace E. A., and Rascovsky, (1938). Rev. neurol. B. Aires, 3, 149.

Gasul, B. M. (1930). Amer. F. Dis. Child., 39, 595.

Greenfield, J. G. (1933). F. Neurol. Psychopath., 13, 289.

Hagberg, B., Sourander, P., Svennerholm, L., and Voss, H. (1969). Acta paediat. (Uppsala), 49, 135.

Hain, R. F., and LaVeck, G. D. (1958). Pediatrics, 22, 1064.

Hansen, E., Olsen, S., and Plum, C. M. (1961). Acta neurol. scand 37, 208.

Hariga, J. (1960). F. Génét. hum., 9, 87.

Heuyer, G., Lhermitte, J., and Vogt, C. (1934). ibid., 2, 843

-, Vogt, C., and Roudinesco (1933). Rev. neurol., 2, 856.

Isler, W., Bischoff, A., and Esslen, E. (1963). Helv. paediat. Acta 18, 107 .

Jacobi, M. (1947). Virchows Arch. path. Anat., 314, 460.

Jakob, C., and Gonzalez, T. (1936). Arch. argent. Neurol., 14, $5 \mathrm{I} \mathrm{N}$

Jervis, G. A. (1960). F. Neuropath. exp. Neurol., 19, 323.

Kalicanin, P. (1962). Neuropsihijatrija, 10, 131.

Kufs, H., Lange-Cosack, H., and Suckow, J. (1954). Psychiet. Neurol. med. Psychol. (Lpz.), $6,12$.

Lange, C. de (1946). Ann. paediat. (Basel), 167, 169.

- (1947). ibid., 168, 138.

Leslie, D. A. (1952). F. Path. Bact., 64, 84I.

Lyon, G., Arthuis, M., and Thieffry, S. (1961). Rev. neurol., 10

508.
Marggraf, K. (1939). Verh. dtsch. Ges.Verdau-u. Stoffwechselkr., $\mathbb{\complement}_{4}$, I08.

Mossakowski, M., Mathieson, G., and Cumings, J. N. (1967?. Brain, 84, 585 .

Norman, R. M., Urich, H., and Tingey, A. H. (1960). ibid., 369.

Ogawa, K. (1961). Arch. Neurol. (Chic.), 4, 4 I8. 
Peiffer, J. (1959). Arch. Psychiat. Nervenkr., 199, 386.

Valdés, J. M., and Piantoni, C. (1933). Arch. argent. Pediat., 4, 556.

Prot, J., and Sobkowicz, H. (1963). Neurol. Neurochir. Psychiat. pol., 13, 339.

Scheidegger, S. (1950). Schweiz. Z. allg. Path., 13, 74.

- (1959). Ann. paediat. (Basel), 193, I.

Slaczka, A. (1938). Zbl. ges. Neurol. Psychiat., 88, 179. [Abstr. of (1937) Neurol.pol., 20, 371.]

Thieffry, S., and Lyon, G. (1959). Rev. neurol., 100, 452.

Van Bogaert, L., and Bertrand, I. (1933). Rev. neurol., 2, 249.

- , and Scholz, W. (1932). Z. ges. Neurol. Psychiat., 141, 5 Io.

Vries, E. de (1954). Folia psychiat. neerl., 57, 196.

Wohlwill, F. J., and Paine, R. S. (1958). Neurology (Minneap.), 8 , 285.

Wolfe, H. J., and Pietra, G. G. (I964a). Amer. F. Path., 44, 92 I. $\longrightarrow$, and - (1964b). New Engl. F. Med., 267, I 198. 